\title{
sciendo
}

DOI 10.2478/sbe-2019-0038

SBE no. 14(2) 2019

\section{DO ENTREPRENEURIAL ATTITUDES EXPLAIN THE RISING INTERNATIONAL BUSINESS ORIENTATION IN DEVELOPING AND EMERGING ECONOMIES?}

\author{
VOGIATZOGLOU KLIMIS \\ National Sun Yat-Sen University, Taiwan
}

\begin{abstract}
:
This paper examines the characteristics that relate to a country's entrepreneurial attitudes, perceptions, intentions, and aspirations for 17 developing and emerging economies during the 20022016 period. Many of those countries have recorded high economic growth rates and have increasingly become more outward-oriented in terms of both, exporting activities as well as direct investments abroad. The empirical analysis is based on survey data from the Adult Population Survey of the Global Entrepreneurship Monitor (GEM) project. We create an overall entrepreneurial attitude index (taking values between 0 and 100) from 6 underlying GEM entrepreneurial attitude indicators. In addition to examining relevant cross-country patterns and trends, a statistical analysis is conducted to test whether a more positive entrepreneurial attitude in a country is associated with a higher international business orientation. The findings indicate that there has been an increase in the overall entrepreneurial attitude index on average, but there are different trends among countries. Most importantly, the results show that improved entrepreneurial attitudes do not explain the increasing international business orientation that has been observed during the sample period. This suggests that in the developing and emerging economies under study other factors were strongly driving the expansion of international business activities.
\end{abstract}

Key words: Entrepreneurial Attitudes; Developing and Emerging Economies; International Business Orientation; Exporting; Direct Investments Abroad

\section{Introduction}

In modern and well-established free market economies, entrepreneurship is at the forefront of private economic activity, investment, and business creation, and thus of detrimental importance to economic growth and prosperity (e.g. Kirzner, 1973, 1997; Salvino et al., 2014; Prieger et al., 2016; Stuetzer et al., 2018; Dhahri and Omri, 2018). Advanced and developed countries have a long history with respect to free market economies and pro-active entrepreneurial culture. With the rising share of new knowledge and innovation activities in the economy as well as sophisticated service activities, the role 
of entrepreneurship and start-ups is growing. Entrepreneurship increasingly accounts for the creation of new sectors and business initiatives driving the economic growth and development process (e.g. Galindo and Mendez, 2014; Lin, 2018; Sobel and Clark, 2018; Stuetzer et al., 2018).

In developing and emerging economies the free market mechanism is less well developed and entrepreneurs and private investments face generally hurdles and less favorable conditions. In many of those countries, government investments and initiatives as well as foreign multinational corporations (MNCs) account for a large share of economic activity (e.g. Vogiatzoglou and Nguyen, 2016; Banerjee and Nayak, 2017), whilst entrepreneurial culture and private initiatives are less well-established (e.g. Kantis et al., 2002). However, in certain policy circles and the business community, it is acknowledged that there is a need for stimulating local entrepreneurship and private businesses in order to play a greater role in the economy and development process. This extends to the outwardness of the economy and international business expansion. In general, most of the internationalization of developing economies is driven by attracting inward foreign direct investment (FDI) from foreign MNCs, which contributes to well-needed capital, production, and exports.

In an increasingly integrated world economy there are plenty of opportunities for local entrepreneurs in emerging economies to engage more actively in international business operations. In certain developing economies various government interventions (such as export subsidies or tax incentives to promote exporting by domestic firms) have been taken to stimulate those activities. Along with long-established large domestic "national champion" firms, government initiatives still drive (either directly or indirectly) a great deal of international business related activities (e.g. Smith and Trebilcock, 2001).

However, in modern economies a key factor of the drive and success of international business engagement is the status of the domestic business-oriented market with particular reference to the attitudes towards entrepreneurship, risk taking, and new ventures. A business environment with an enhanced entrepreneurial culture is more likely to engage in more risky international business operations (where the information and experience of foreign markets is relatively less compared to the domestic market). Over the years, with increased exposure to international trade and market reforms, developing and emerging economies have made some steps towards more free-market oriented economies and entrepreneurship.

Therefore, the aim of this paper is, first, to analyze the entrepreneurial attitudes, aspirations, and intentions that are prevalent in developing and emerging economies. In addition to a cross-country view, we also examine the developments and changes in entrepreneurial attitudes over time. Secondly, the study's objective is to statistically test whether or not there is an association between a country's attitudes towards entrepreneurship and a country's international business expansion and orientation, in terms of exporting as well as investing and conducting operations abroad. More specifically, we study 17 developing and emerging economies over the 2002-2016 period, for which we can create a panel-dataset of relevant variables.

The remainder of the paper is organized as follows. The next section gives a brief overview of the relevant literature and conceptual framework. Section three presents the 
data related to entrepreneurial attitudes and international business orientation indicators. It also provides a descriptive statistical analysis of the observed cross-country patterns over time. Section 4 analyzes statistically the relationship between a country's entrepreneurial attitudes and international business outcomes. Finally, section 5 concludes.

\section{Literature and Conceptual Framework}

Though its significance is universally acknowledged, there is less consensus on the precise definition or meaning of entrepreneurship. Over the years various aspects and interpretations have been attached to the term, which was first coined by Cantillon, a French economist. Afterwards many economists essentially accepted Cantillon's view that the basic premise of an entrepreneur consists of a self-employed individual who undertakes and organizes a risky and new business venture (Ahmad and Seymour, 2008). Joseph Schumpeter added the innovation aspect to the term, which is particularly relevant in the context of the contemporary economy in our era (Schumpeter, 1934). In fact, the issue of what exactly constitutes entrepreneurship and how to precisely measure it, represents an active area of research and ongoing debate among scholars (e.g. Shane, 2003; Sharma and Chrisman, 2007). Instead of going into this debate, we adopt the view of Reynolds et al. (1999), as the conceptual framework and measures of entrepreneurial attitudes, aspirations, and intentions that we use in the empirical analysis are based on them, who developed the Global Entrepreneurship Monitor (GEM) project.

According to this perspective, entrepreneurship is conceived as any "attempt at new business or new venture creation, such as self-employment, a new business organization, or the expansion of an existing business, by an individual, a team of individuals, or an established business" (Reynolds et al., 1999, p. 3). In a nutshell, in the conceptual framework of the GEM, which is depicted in Figure 1, there are three fundamental components in the entrepreneurial process: the national framework (economy) conditions; the social values and attributes with respect to entrepreneurship (which our study specifically focuses on); and observed and measured entrepreneurial activity, resulting into economic outcomes.

The entrepreneurial culture affects the extent of the entrepreneurship activity, which in turns affects business activity and growth outcomes. Our empirical analysis centers around the role of the entrepreneurial attitudes, aspirations, and intentions, as we are particularly interested in examining the effect of this social dimension of entrepreneurship on international business activity outcomes.

In addition to the significance of the social aspect on its own right, there is also another rational for this choice. The social values are not uniform across many developing and emerging economies. There are differences (in some instances considerable) in terms of entrepreneurial culture. Thus, instead of looking at the national economic conditions or at the entrepreneurship activity purely in terms of numbers (how many firms were established), an examination of the role of this entrepreneurial attitude and culture aspect has its merits. 


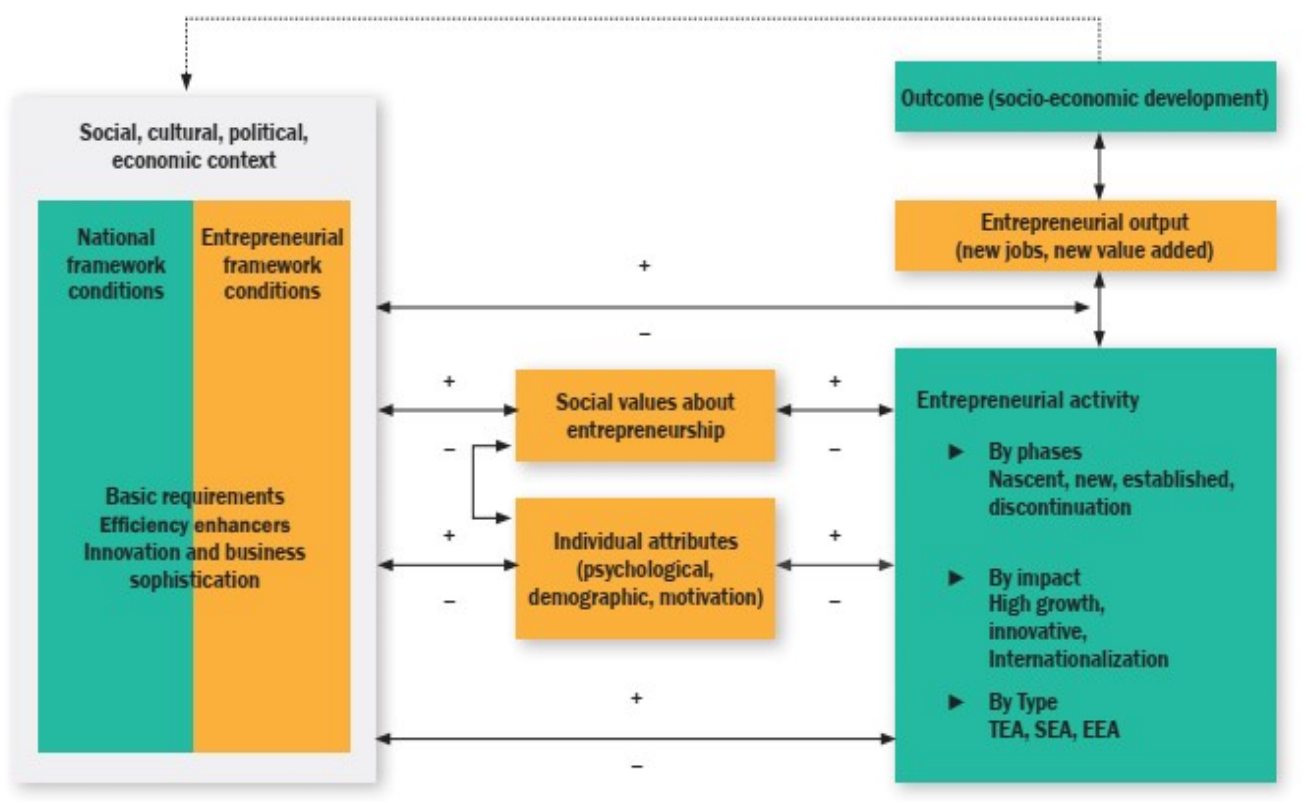

Figure 1. Conceptual framework of entrepreneurship of GEM Source: GEM 2015/2016 Global Report.

Finally, it is worth mentioning that there is a large interest and therefore a large literature on the subject of entrepreneurship in general. Though it is beyond the scope of this section to provide a detailed review of those studies, it can be noted that most of the empirical literature on entrepreneurship focuses on the number of new firm formation (either absolute amount or in relative terms, i.e. per number of total firms or population size). Numerous studies in this literature investigate the contribution of entrepreneurship to economic activity in general or the effect on the economic growth rate (e.g. Carree and Thurik, 2006; Valliere and Peterson, 2009; Prieger et al., 2016).

\section{Data and Indicators}

The data source with regard to entrepreneurial culture is the database of the Adult Population Survey (APS) of the Global Entrepreneurship Monitor (GEM) project.

The APS is a global survey to measure the social characteristics, nature, and activity of entrepreneurship, where 2000 and above respondents are surveyed by the GEM team in each country included in the survey every year during the same period. There is a large availability of information on various areas. The complete list of measures, and definitions are provided on the GEM project database (www.gemconsortium.org).

Based on data availability (for entrepreneurial and other data used in the analysis), our sample is a panel-dataset of 17 developing and emerging countries during 2002-2016. Table 1 shows the countries included in the sample. 


\section{Table 1. Country sample}

\begin{tabular}{|c|c|c|c|c|}
\hline 1. Argentina & 5.Colombia & 9. Malaysia & 13. Philippines & 17. Uruguay \\
\hline 2. Brazil & 6. Ecuador & 10. Mexico & 14. South Africa & \\
\hline 3. Chile & 7. India & 11. Panama & 15. Thailand & \\
\hline 4. China & 8. Indonesia & 12. Peru & 16. Turkey & \\
\hline
\end{tabular}

For the purpose of our research study, we consider only the measures that relate to entrepreneurial attitudes, perceptions, intentions, and aspirations (in order to create an overall measure entrepreneurial attitude and culture). Those are shown in Table 2.

\section{Table 2. Entrepreneurial attitude indicators}

Measure Definition

(1) Perceived

Opportunities

(2) Perceived

Capabilities

(3) Fear of Failure

(4) Entrepreneurial Intentions

(5) High Status to Successful Entrepreneurs

(6) Entrepreneurship as a Good Career Choice
Percentage of 18-64 population who see good opportunities to start a firm in the area where they live

Percentage of 18-64 population who believe they have the required skills and knowledge to start a business

Percentage of 18-64 population perceiving good opportunities to start a business who indicate that fear of failure would prevent them from setting up a business

Percentage of 18-64 population (individuals involved in any stage of entrepreneurial activity excluded) who are latent entrepreneurs and who intend to start a business within three years

Percentage of 18-64 population who agree with the statement that in their country, successful entrepreneurs receive high status

Percentage of 18-64 population who agree with the statement that in their country, most people consider starting a business as a desirable career choice

All measures, except (3), relate positively to a more pro-active and motivated entrepreneurial culture. In order to create an overall indicator, we first invert measure (3) to reflect positive attitude (no fear of failure). Then we convert every indicator into a 0-100 index by means of a (linear min-max) normalization to a 0-100 range (where the min and max values refer to the country sample), as follows:

$$
E_{i t}^{0-100}=\frac{E_{i t}-\min (E)}{\max (E)-\min (E)}
$$


where $\mathrm{E}$ is one of the six entrepreneurial attitude indicators, $\mathrm{i}$ denotes countries and $\mathrm{t}$ refers to time point (year). Finally, those six calculated 0-100 indicators are averaged to derive an overall entrepreneurial attitude. Higher values correspond to better entrepreneurial culture. This represents our overall entrepreneurial attitude index, with which we conduct our empirical analysis. In Table 3 we report the descriptive statistics for the six original GEM indicators and our 0-100 entrepreneurial attitude index. In general, it seems that the attitudes towards entrepreneurship are not very high/positive, but there are variations across countries. South Africa and China exhibit in many indicators and in the overall index the lowest value, whilst Colombia and Brazil show rather high indicator values.

Table 3. Descriptive statistics of entrepreneurial attitude indicators and overall 0-100 index

\begin{tabular}{|c|c|c|c|c|}
\hline Indicator & $\begin{array}{l}\text { Mean } \\
\text { Value }\end{array}$ & $\begin{array}{l}\text { Standard } \\
\text { Deviation }\end{array}$ & $\begin{array}{l}\text { Min. } \\
\text { Value }\end{array}$ & $\begin{array}{l}\text { Max. } \\
\text { Value }\end{array}$ \\
\hline $\begin{array}{l}\text { Perceived } \\
\text { Opportunities }\end{array}$ & 43.74 & 12.02 & $\begin{array}{c}13.62 \\
\text { (South Africa) }\end{array}$ & $\begin{array}{c}73.06 \\
\text { (Colombia) }\end{array}$ \\
\hline $\begin{array}{l}\text { Perceived } \\
\text { Capabilities }\end{array}$ & 53.35 & 13.54 & $\begin{array}{l}22.55 \\
\text { (China) }\end{array}$ & $\begin{array}{l}78.01 \\
\text { (Peru) }\end{array}$ \\
\hline Fear of Failure & 32.78 & 8.28 & $\begin{array}{l}13.91 \\
\text { (China) }\end{array}$ & $\begin{array}{c}65.32 \\
\text { (Malaysia) }\end{array}$ \\
\hline $\begin{array}{l}\text { Entrepreneurial } \\
\text { Intentions }\end{array}$ & 27.27 & 13.43 & $\begin{array}{c}3.64 \\
\text { (South Africa) }\end{array}$ & $\begin{array}{c}62.56 \\
\text { (Colombia) }\end{array}$ \\
\hline $\begin{array}{l}\text { High Status to } \\
\text { Entrepreneurs }\end{array}$ & 66.77 & 12.94 & $\begin{array}{c}3.35 \\
\text { (South Africa) }\end{array}$ & $\begin{array}{l}86.33 \\
\text { (Brazil) }\end{array}$ \\
\hline $\begin{array}{l}\text { Entrepreneurship as } \\
\text { a Good Career Choice }\end{array}$ & 67.18 & 15.14 & $\begin{array}{c}3.97 \\
\text { (South Africa) }\end{array}$ & $\begin{array}{c}92.45 \\
\text { (Colombia) }\end{array}$ \\
\hline Overall Index & 56.54 & 14.74 & $\begin{array}{c}1.99 \\
\text { (South Africa) }\end{array}$ & $\begin{array}{c}84.05 \\
\text { (Colombia) }\end{array}$ \\
\hline
\end{tabular}

The other two key variables relate to two basic forms of a country's international business, namely exports (EXP) and outward foreign direct investment (OFDI). Since first we have in our sample economies with large country size differences, and secondly we are interested in a country's extent, degree, or relative importance of international business in the country's economy, we measure both EXP and OFDI in per capita terms. EXP is calculated from export value (in US dollars) data and population data obtained from the World Development Indicators (WDI), World Bank. OFDI is obtained from the UNCTAD 
FDI database. In Table 4 we report the descriptive statistics for those international business indicators.

Table 4. Descriptive statistics of international business indicators

\begin{tabular}{lcccc}
\hline Indicator & $\begin{array}{l}\text { Mean } \\
\text { Value }\end{array}$ & $\begin{array}{c}\text { Standard } \\
\text { Deviation }\end{array}$ & $\begin{array}{c}\text { Min. } \\
\text { Value }\end{array}$ & $\begin{array}{c}\text { Max. } \\
\text { Value }\end{array}$ \\
\hline $\begin{array}{l}\text { Exports } \\
\text { per capita }\end{array}$ & 1928.90 & 1822.66 & $\begin{array}{c}67.19 \\
\text { (India) }\end{array}$ & $\begin{array}{c}8870.93 \\
\text { (Malaysia) }\end{array}$ \\
$\begin{array}{l}\text { Outward FDI } \\
\text { per capita }\end{array}$ & 714.98 & 1175.99 & $\begin{array}{c}3.27 \\
\text { (Indonesia) }\end{array}$ & $\begin{array}{c}6071.61 \\
\text { (Chile) }\end{array}$ \\
\hline
\end{tabular}

In Figure 2 we show the average EXP, OFDI, and overall entrepreneurial attitude index in 2002 and 2016. As it is evident, there has been a significant increase in the two international business indicators between these two time points. The country average entrepreneurial index has also increased during this time period.

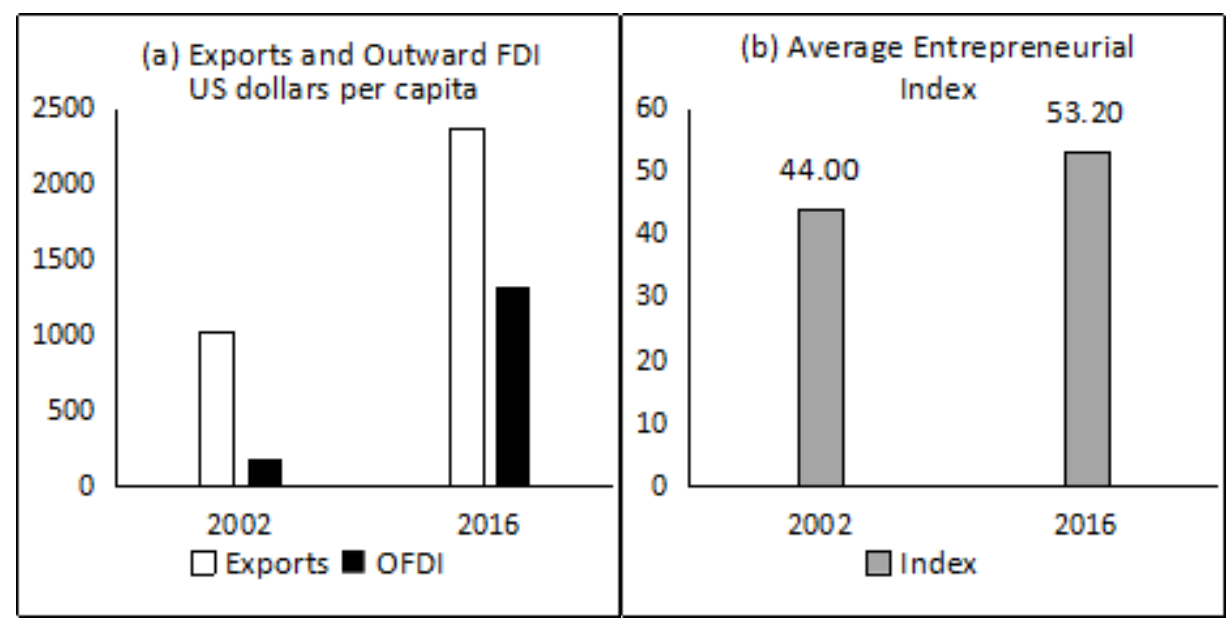

Figure 2. Country average indicators in 2002 and 2016

However, we have to note that there are substantial differences in the trends in various countries. In some countries the overall index clearly shows a strong upward trend (e.g. Argentina, Brazil, Chile, Indonesia), whilst in others it rather increases slightly (e.g. Thailand, Turkey) or remains about the same level (e.g. China, Colombia, Ecuador, India, Mexico). Some economies have experienced a decline the index between 2002 and 2016, suggesting a worsening in entrepreneurial attitudes and intentions (e.g. Malaysia, Peru, Uruguay). 


\section{Statistical analysis}

Many developing and emerging economies have, indeed, expanded their international business activities and their economies have increasingly become more outward oriented (UNCTAD, 2017; 2018). The previous section has also provided some evidence on that. The relevant question that can be asked is if this considerable international business expansion and orientation is associated with improvements in entrepreneurial attitudes, and if so what is the quantitative effect of improved entrepreneurial aspirations on the magnitude of a country's international business orientation in the case of developing and emerging economies.

The conceptual discussion in section 2, provided some general insights and possible expectations on economic outcomes including a country's outwardness and international business outcomes. More specifically, as a more pro-active and motivated entrepreneurial attitude is expected to contribute to more entrepreneurial activity, we study whether or not it relates to a higher extent of internationalization of the domestic economy. In particular, we test two hypotheses:

A. Countries with more pro-active and motivated entrepreneurial attitudes (as evidenced by the overall entrepreneurial index) exhibit a higher export orientation and performance.

B. Countries with more pro-active and motivated entrepreneurial attitudes (as evidenced by the overall entrepreneurial index) exhibit a higher orientation in international investment and business operations abroad.

With empirical economic data, those hypotheses can be tested through statistical analysis. A general approach is to first examine the strength of the association of the variables under study by conducting a correlation analysis. This gives a first picture of a possible relationship between the variables. Once a statistically significant association has been found (especially if it shows a strong relationship), further analyses can be conducted. This includes econometric modelling to analyze the quantitative impact of the variable of interest (in our case it is the entrepreneurial index) that is assumed to exert an influence on the dependent variable (in our case the two international business indicators, EXP and OFDI), while controlling for other factors.

Thus we first conduct two correlation analyses, where the Pearson correlation coefficient is calculated. This coefficient shows whether or not there is a statistically significant linear relationship between two variables. It takes values between -1 and 1 , where a negative value indicates a negative relationship, and a positive value indicates the relationship is positive (i.e. the two variables move into the same direction). The results of the first correlation analysis, which is between the overall entrepreneurial index and the export variable, are shown in Figure 3. From the figure (which is a scatterplot with the entrepreneurial index on the x-axis and the export variable on the $y$-axis) it can be easily discerned that there does not seem to be any sort of systematic relationship (linear or otherwise) between those two variables. In particular, the Pearson correlation coefficient is -0.0321 (a very low value) and is statistically insignificant ( $p$-value is 0.6318 ). This means that statistically this coefficient value is 0 , and thus there is no association between the variables. 


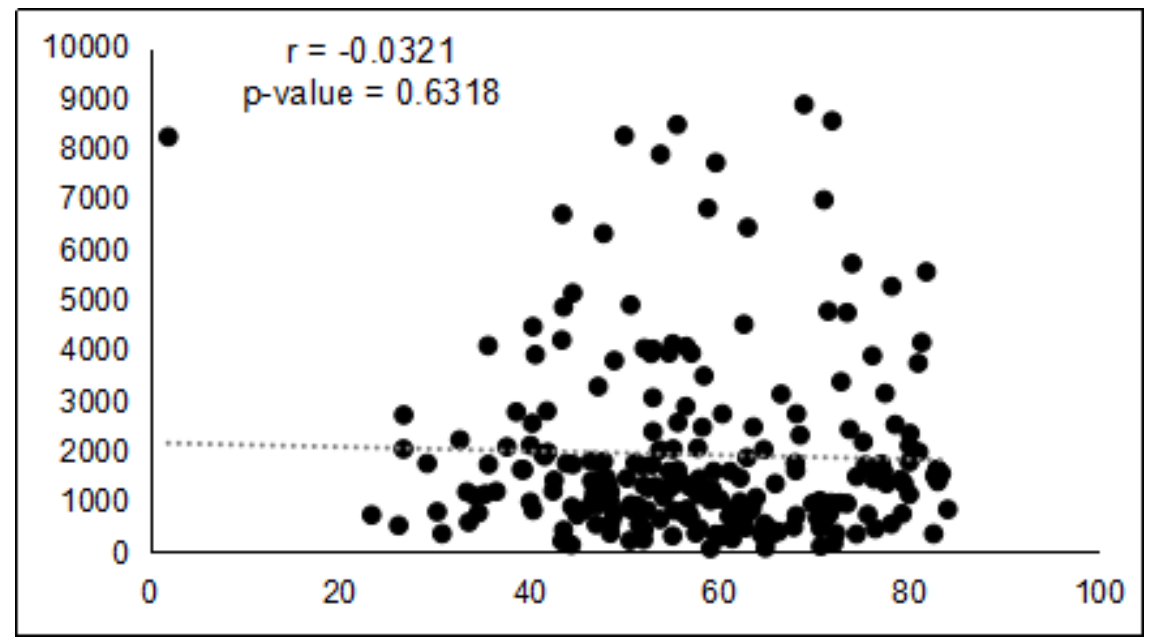

Figure 3. Correlation analysis between entrepreneurial index and exports per capita

Figure 4 depicts the scatterplot and the results of the correlation analysis for the entrepreneurial index and the OFDI variable. As it can be seen, again there does not appear to exist any systematic relationship. However, the Pearson correlation coefficient in this case is slightly higher (in absolute terms and again negative) and almost statistically significant at the $10 \%$ level (p-value: 0.1037 ). We can take this as evidence of no relationship between the two variables.

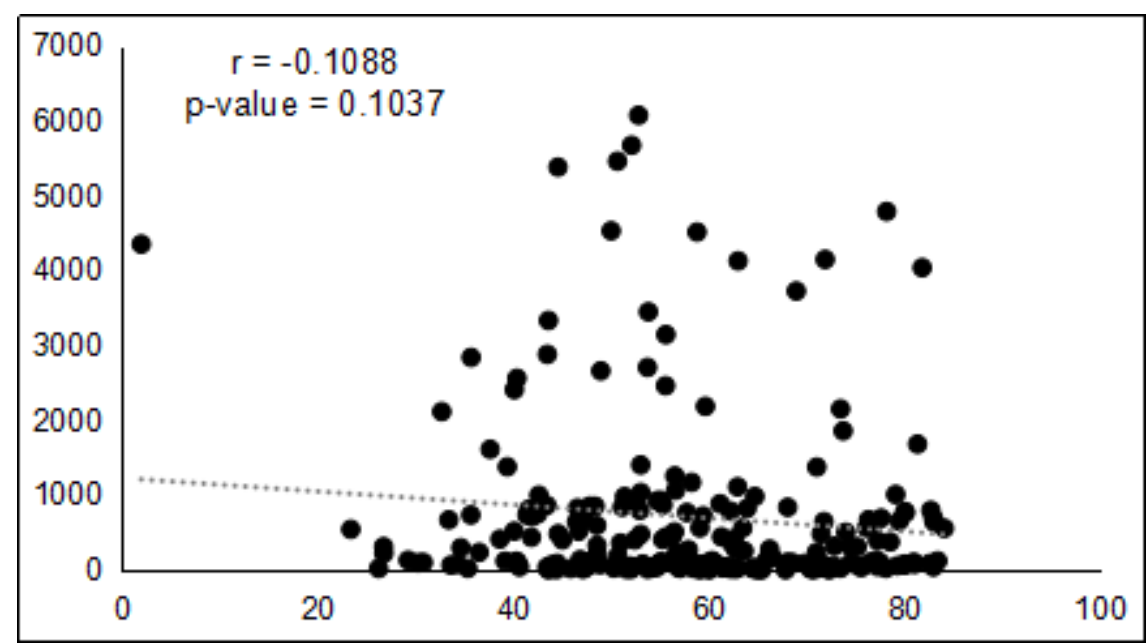

Figure 4. Correlation analysis between entrepreneurial index and OFDI per capita

As the two correlation analyses clearly show evidence of no association, further analyses need not to be conducted. A higher extent of pro-entrepreneurial attitude is not associated with a higher extent of a country's international business orientation. Thus, both hypotheses fail this first statistical test and we conclude that we cannot assume that in our country sample a better entrepreneurial attitude leads to more export activity or more investments abroad. 


\section{Concluding Remarks}

In this paper, for 17 developing and emerging economies during the 2002-2016 period we have examined the characteristics that relate to a country's entrepreneurial attitudes, perceptions, intentions, and aspirations. Based on data from the GEM project database, we have created an overall entrepreneurial attitude index (taking values between 0 and 100) from 6 underlying GEM indicators.

Through statistical analysis we have tested whether or not a more positive and motivated entrepreneurial attitude in a country is associated with increased international business orientation, as indicated by exporting and direct investments abroad (outward foreign direct investment). It was found that entrepreneurial attitude is not correlated with both aspects of a country's internationalization (exports and outward FDI). This indicates that the considerable and in some cases impressive international business expansion that has been achieved in the developing and emerging economies in our sample during the 2002-2016 period cannot be explained and be attributable to differences in entrepreneurial attitudes.

We have to note that our findings might be to some extent due to the entrepreneurial attitude measure we use. However, other studies using the GEM database for other countries do find evidence of a positive link with various economic outcomes (e.g. Carree and Thurik, 2006; Valliere and Peterson, 2009; Prieger et al., 2016). Furthermore, we have seen that there is variation in the entrepreneurial attitudes among the countries under study, which are picked up by our measure. Perhaps, a much greater variation with very large differences in the attitudes would have produced a noticeable association with the two international business indicators.

The most likely, explanation, though, seems that, instead of entrepreneurial attitudes, there are other factors and determinants that explain the international business expansion of those countries. There are several studies that point to several critical factors of the rising internationalization and outwardness that is observed in many of those economies. These factors relate, for instance, to the role of foreign MNCs (e.g. Vogiatzoglou and Nguyen, 2016; Banerjee and Nayak, 2017), which account for a large share of a host-country's total exports, or to the role of governments play in promoting and even directly operating various economic activities leading to exporting and investments abroad (e.g. Smith and Trebilcock, 2001).

It is worth stressing that the most striking feature of our findings is not so much that differences in entrepreneurial attitudes do not correlate with international business performance indicators, but the magnitude of this lack of association. Combined with the findings of studies of the determinants mentioned above, we can interpret this as pointing to the complete irrelevance of positive entrepreneurial attitudes as a determinant of a country's international business expansion and orientation in the case of the developing and emerging economies we have examined. Finally, though, there is generally a severe dearth of relevant data, in order to clarify this further, a comprehensive research is needed to analyze a larger sample of developing countries and examine several alternative entrepreneurial attitude indicators. 


\section{References}

Ahmad, N., Seymour, R., (2008), Defining Entrepreneurial Activity: Definitions Supporting Frameworks for Data Collection, OECD Statistics Working Papers, No. 2008/01, OECD Publishing, Paris, France.

Banerjee, T., Nayak, A., (2017), Multinational investments and product sophistication, Economics Letters, Vol. 161, issue C, pp. 157-163.

Carree, M., Thurik, R. (Eds.), (2006): Entrepreneurship And Economic Growth, Edward Elgar Publishing, Cheltenham, UK.

Dhahri, S., Omri, A., (2018), Entrepreneurship contribution to the three pillars of sustainable development: What does the evidence really say?, World Development, Vol. 106, issue C, pp. 64-77.

Galindo, M.A., Mendez, M.T., (2014), Entrepreneurship, economic growth, and innovation: Are feedback effects at work?, Journal of Business Research, Vol. 67, no. 5, pp. 825-829.

GEM, (2016): 2015/2016 Global Report, Global Entrepreneurship Monitor, Global Entrepreneurship Research Association, London Business School, London, UK.

Kantis, H., Ishida, M., Komori, M., (2002): Entrepreneurship in emerging economies: the creation and development of new firms in Latin America and East Asia, Inter-American Development Bank, Washington, D.C., USA.

Kirzner, I., (1973): Competition and Entrepreneurship, University of Chicago Press, Chicago, Illinois, USA.

Kirzner, I., (1997), Entrepreneurial Discovery and the Competitive Market Process: An Austrian Approach, Journal of Economic Literature, Vol. 35, no. 1, pp. 60-85.

Lin, O.C.C., (2018): Innovation and Entrepreneurship: Choice and Challenge, World Scientific Publishing, Singapore.

Prieger, J., Bampoky, C., Blanco, L., Liu, A., (2016), Economic Growth and the Optimal Level of Entrepreneurship, World Development, Vol. 82, pp. 95-109.

Reynolds, P., Hay, M., Camp, M., (1999): Global Entrepreneurship Monitor - 1999 Report, Kauffman Center for Entrepreneurial Leadership, Ewing Marion Kauffman Foundation, Kansas City, Missouri, USA.

Salvino Jr., R., Tasto, M., Randolph, G., (2014): Entrepreneurial Action, Public Policy, and Economic Outcomes, Edward Elgar Publishing, Cheltenham, UK.

Schumpeter, J., (1934): The Theory of Economic Development: An Inquiry into Profits, Capital, Credit, Interest, and the Business Cycle, Harvard University Press, Cambridge, MA, USA.

Shane, S., (2003): A General Theory of Entrepreneurship: The Individual-Opportunity Nexus, Edward Elgar Publishing, Cheltenham, UK.

Sharma, P., Chrisman, J., (2007), Toward a Reconciliation of the Definitional Issues in the Field of Corporate Entrepreneurship, in: Cuervo A., Ribeiro D., Roig S., (Eds.), Entrepreneurship, Springer-Verlag Berlin Heidelberg, Germany.

Smith, D.A., Trebilcock, M.J., (2001), State-Owned Enterprises in Less Developed Countries: Privatization and Alternative Reform Strategies, European Journal of Law and Economics, Vol. 12, no. 3, pp. 217-252.

Sobel, R., Clark, J., (2018), The use of knowledge in technology entrepreneurship: A theoretical foundation, The Review of Austrian Economics, Vol. 31, no. 2, pp. 195-207.

Stuetzer, M., Audretsch, D., Obschonka, M., Gosling, Rentfrow, P., Potter, J., (2018), Entrepreneurship culture, knowledge spillovers and the growth of regions, Regional Studies, Vol. 52, no. 5, pp. 608-618.

UNCTAD, (2017): Trade and Development Report 2017 - Beyond austerity: Towards a global new deal, United Nations Conference on Trade and Development, Geneva, Switzerland. 
UNCTAD, (2018): World Investment Report 2018 - Investment and New Industrial Policies, United Nations Conference on Trade and Development, Geneva, Switzerland.

Valliere, D., Peterson, R., (2009), Entrepreneurship and economic growth: Evidence from emerging and developed countries, Entrepreneurship and Regional Development, Vol. 21, no.5-6, pp.459-480.

Vogiatzoglou, K., Nguyen, P.N.T., (2016), Economic Openness and Economic Growth: A Cointegration Analysis for ASEAN-5 Countries, European Journal of Applied Economics, Vol. 13, no. 2, pp. 10-20. 